\title{
Relationships between Heavy Metal Concentrations in the American Oyster (Crassostrea virginica) and Metal Levels in the Water Column and Sediment in Apalachicola Bay, Florida
}

\author{
Dennis A. Apeti, Larry Robinson and Elijah Johnson \\ Environmental Sciences Institute, Florida Agricultural and Mechanical University \\ 1520 South Bronough Street Tallahassee, FL. 32307
}

\begin{abstract}
This study aims to assess baseline concentrations of heavy metals $(\mathrm{Cd}, \mathrm{Cr}, \mathrm{Cu}, \mathrm{Pb}$ and $\mathrm{Zn})$ in the oyster soft tissue as they relate to concentrations in the water column (particulate phase) and sediment in Apalachicola Bay. In order to conduct these assessments, a total of 360 samples, collected in two seasons (winter and summer) and were analyzed using atomic absorption spectrometry. Results indicated that elemental concentrations in particulate phase correlate significantly with concentration in the tissue than those in the sediment. Moreover, assessment of seasonal and spatial variations have indicated that oysters collected in the winter have significantly higher $(\mathrm{P}<0.05) \mathrm{Cu}, \mathrm{Pb}$ and $\mathrm{Zn}$ concentrations than oysters collected in the summer. However, metal concentrations in sediment did not show such patterns. These observations confirmed the fact that metals in the particulate phase are more bioavailable to oysters and that the oysters can be used as good indicators of the spatial and temporal variation of the heavy metals in the aquatic system.
\end{abstract}

Key words: Heavy metals, estuary, Crassostrea virginica, surficial sediment, particulate matter

\section{INTRODUCTION}

Apalachicola Bay, located in the Florida panhandle on the coast of the Gulf of Mexico, is a very productive fresh water dominated estuary. The bay is of a very significant ecological and commercial importance. As such, the bay acts like a nursery and spawning ground for many aquatic wildlife and it supports the largest shellfish (oyster, shrimp and blue crab) fisheries in the State of Florida. Although the Apalachicola Bay is been considered to be quasi unpolluted, more and more evidence of high levels of heavy metal in the estuarine sediment have being liked to sources that are anthropogenic as well as natural ${ }^{[1]}$. Erosion of the underlining geological formation by the Apalachicola River, the main supplier of freshwater, constitutes the sole possible natural source of metals in the $\mathrm{Bay}^{[2]}$. Whereas, anthropogenic sources include dredging, certain uses of land and water within the drainage basin, inadequate sewage treatment, as well as local and regional industrial emissions ${ }^{[3]}$. Once in the estuarine environment, fluctuations of water physical parameters, such as salinity and $\mathrm{pH}$, usually render these metals somewhat bioavailable and they ultimately bioaccumulate in organisms ${ }^{[4]}$.

Due to the decreasing trend of the water quality in the bay, it is therefore important to conduct a baseline study on ubiquitous and persistent contaminants such heavy metals in the bay.
Previous studies have determined levels of metal concentrations in the Apalachicola estuary ${ }^{[2,3]}$. However these studies did not investigate how elemental concentrations in oyster soft tissue correlate with concentration in the water column and sediment.

The aim of this study is to assess the relationships between metal $(\mathrm{Cd}, \mathrm{Cr}, \mathrm{Cu}, \mathrm{Pb}$ and $\mathrm{Zn})$ concentrations in the soft tissue of $C$. virginica and elemental concentrations in the surrounding environment, particularly the water column and the surficial sediments in Apalachicola Bay. Other objectives are to determine trends of spatial and temporal variations in concentrations of metals in $C$. virginica. To achieve these objectives, oyster, sediment and water samples were collected from six sites in the main bay during the low river flow season (spring-summer) in 2002 and the high river flow season (fall-winter) in 2003.

As part of an effort to continue monitoring the ecological health of the Apalachicola estuary this study is important as its unique approach to establish the relationships between metal bioaccumulation in the oyster and metal concentrations in water and sediments, provides additional information on the baseline concentration of the selected metals in Apalachicola Bay. The significance of seasonal and temporal variations, as well as the correlations between the selected metals in $C$. virginica, water and surficial sediments, are reported and discussed.

Corresponding Author: Dennis A. Apeti, Environmental Sciences Institute, Florida Agricultural and Mechanical University, 1520 South Bronough Street Tallahassee, FL. 32307 


\section{MATERIALS AND METHODS}

Study area: Apalachicola Bay is a coastal estuary with barrier islands and significant freshwater input. The Bay together with its Sounds, acts like a transitory buffer zone between the freshwater of the Apalachicola River and the saline water of the Gulf of Mexico. The Apalachicola River is formed by the confluence of the Chattahoochee and Flint Rivers. Based on patterns of water movement in the bay ${ }^{[2]}$, six sites were selected along two transect patterns (Fig. 1). The sites were selected to follow the flow of fresh and saline water into the Bay. A differential GPS instrument was utilized to accurately locate the sites and facilitate repetitive sampling.

Sampling and analytical procedures: In order to determine possible seasonal variations of trace metals in the oyster, $C$. virginica, water and surficial sediment sample collection were conducted during low (springsummer) and high (fall-winter) Apalachicola River flow. Sample collection and preservation techniques were adopted from the method described in the Guidance Document for Metals in Shellfish ${ }^{[5]}$ and the NS\&T mussel watch project ${ }^{[6]}$. Sediment and surface water were collected in five replicates. For quality control purposes all containers were acid washed and gloves were worn and changed after each task, to prevent cross-contamination.

Oyster and sediment: Oyster samples were collected using oyster-tongs. The animals were kept in plastic bags and placed on ice. In the laboratory, harvestable oysters of 7-8 cm shell length were selected and thoroughly cleaned to remove adhering sediments. For each replicate, 10 animals were selected and shucked following a modified method described for the US Food and Drug Administration ${ }^{[5]}$. Surficial sediments were collected using a gravity corer from the Aquatic Instrument Inc. Samples were kept on ice until transported to the laboratory. The top $10 \mathrm{~cm}$ of each sediment core was carefully taken and manually stirred in a glass tray using a heavy-duty porcelain spatula. The pasty sediment samples were then sifted using a 40 points sieve to get rid of shell fragments and other large debris. Aliquots of 60 to 70 grams were place in acidwashed disposable plastic beakers and freeze-dried.

Although separately analyzed, oyster tissue and sediment samples were digested and analyzed following the same analytical technique. In addition, all preparatory work, samples and standard dilutions, blanks and all other quality control (QC) solutions were performed using ultra pure water with a quality of 18 $\mathrm{M} \Omega \mathrm{cm}^{-1}$ resistivity. Digestion of the oyster tissue and sediments were conducted following the US Environmental Protection Agency (EPA) certified Method 3050B. Interested readers should refer to the method for detailed information. Elemental analyses were conducted using flame atomic absorption spectrometer

The instrument was set to analyze each sample in triplicate and quality control tests on the calibration curves were set as follows: 3 replicates with RSD $<5$ $\%, \mathrm{r}^{2}>0.99$ and calibration standards were within 20 $\%$. Calibration check solutions Certiprep ICQ-100-21 and IC-21 from Fisher Scientific were continuously analyzed to check any drift in the calibration. Standard reference materials SRM-1566b (oyster tissue) and SRM-1646a (estuarine sediments) from the National Institute of Standard and Technology (NIST) were analyzed to check the accuracy and efficiency of the analytical procedure.

Water: Surface water was collected at a depth of $1 \mathrm{~m}$ using a vertical water-sampling instrument from Aquatic Instrument Inc. The instrument, which uses a suction mechanism, allows on-board collection at a specific depth. The water samples were poured into $1000 \mathrm{ml}$ pre-labeled polyethylene (PE) plastic containers and maintained at $4{ }^{\circ} \mathrm{C}$ in coolers.

In the laboratory, water samples were homogenized and vacuum filtered using $0.45 \mu \mathrm{m}$ pre-washed and preweighed membranes. The filtrates containing dissolved metals were poured into clean PE containers then acidified to a $\mathrm{pH}$ of less than 2 .

The membranes with particulate matter were dried in an oven at $40{ }^{\circ} \mathrm{C}$ for 12 hours, then weighed again and carefully transferred into digestion vessels. The digestion of the water sample was based on the EPA certified method 3020A.

The analyses of saltwater and membranes were based on the EPA method 200.12 $2^{[7]}$. The atomic absorption spectrometry instrument Fast-Sequence FS220 with graphite furnace capability was utilized. Calibration checked solutions (ICQ-100-21 and IC-21) from Certiprep were continuously analyzed in order to check any drift in the calibration. To check for accuracy of the analytical method SRMs $3108 \mathrm{Cd}, 3114 \mathrm{Cu}$, $3128 \mathrm{~Pb}$ and $3168 \mathrm{Zn}$ from NIST were also analyzed.

Statistical analysis: Statistical analyses were performed using GraphPad Statistical software, Prism 3.0 and Microsoft Excel. One-way analysis of variance (ANOVA) coupled with the Tukey-Kramer multiple range tests were conducted to differentiate between mean pairs ${ }^{[8]}$. The relationships between the elemental concentrations in oyster tissue, sediments and water were evaluated by linear regression and the determination of Pearson correlation coefficients. All errors were calculated at the $95 \%$ confidence level.

\section{RESULTS}

Quality control: The accuracy of the analytical technique was verified by the analysis of the NIST standard reference materials oyster tissue (SRM-1566b) 
Am. J. Environ. Sci., 1 (3): 179-186, 2005

Table 1:Quality control performance with SRM-1566b (oyster tissue) and SRM-1646a (estuarine sediment). Values are Mean $\pm 95 \% \mathrm{CL}\left(\mu \mathrm{g} \mathrm{g}^{-1}\right.$ dry-weight)

\begin{tabular}{|c|c|c|c|c|c|c|}
\hline \multirow[b]{2}{*}{ Metals } & \multicolumn{3}{|l|}{ SRM 1566b } & \multicolumn{3}{|l|}{ SRM 1646a } \\
\hline & Measured & Certified & $\%$ Recovery & Measured & Certified & Recovery \\
\hline $\mathrm{Cd}$ & $2.26 \pm 0.43$ & $2.48 \pm 0.08$ & 91.13 & $0.16 \pm 0.04$ & $0.15 \pm 0.01$ & 106.67 \\
\hline $\mathrm{Cr}$ & $1.19 \pm 0.20$ & NA & & $37.7 \pm 0.63$ & $40.9 \pm 1.90$ & 92.18 \\
\hline $\mathrm{Cu}$ & $71.5 \pm 0.97$ & $71.6 \pm 1.60$ & 99.86 & $9.26 \pm 1.14$ & $10.0 \pm 0.34$ & 92.60 \\
\hline $\mathrm{Pb}$ & $0.26 \pm 0.07$ & $0.31 \pm 0.01$ & 83.87 & $9.64 \pm 1.08$ & $11.7 \pm 1.20$ & 82.39 \\
\hline $\mathrm{Zn}$ & $1437 \pm 18$ & $1424 \pm 46$ & 100.91 & $47.2 \pm 1.04$ & $48.9 \pm 1.60$ & 96.52 \\
\hline
\end{tabular}

Data pairs with different letters are significantly different $(\mathrm{P}>0.05)$ with student $\mathrm{t}$-test at $95 \% \mathrm{CL}$

Table 2a: Crassostrea virginica. Elemental concentrations in tissue vs. particulate phase (PP) collected in the summer season

\begin{tabular}{|c|c|c|c|c|c|c|c|c|c|c|}
\hline & $\mathrm{Cd}$ & & $\mathrm{Cr}$ & & $\mathrm{Cu}$ & & $\mathrm{Pb}$ & & $\mathrm{Zn}$ & \\
\hline Sites & Oyst $\left(\mu g g^{-1}\right)$ & $\mathrm{PP}\left(\mu \mathrm{g} \mathrm{L}^{-1}\right)$ & Oyst $\left(\mu \mathrm{g} \mathrm{g}^{-1}\right)$ & $\mathrm{PP}\left(\mu \mathrm{g} \mathrm{L}^{-1}\right)$ & Oyst $\left(\mu \mathrm{g} \mathrm{g}^{-1}\right)$ & $\mathrm{PP}\left(\mu \mathrm{g} \mathrm{L}^{-1}\right)$ & Oyst $\left(\mu \mathrm{g} \mathrm{g}^{-1}\right)$ & $\mathrm{PP}\left(\mu \mathrm{g} \mathrm{L}^{-1}\right)$ & Oyst $\left(\mu \mathrm{g} \mathrm{g}^{-1}\right)$ & $\mathrm{PP}\left(\mu \mathrm{g} \mathrm{L}^{-1}\right)$ \\
\hline$\overline{\text { ST1 }}$ & $2.65 \pm 0.07$ & $5.42 \pm 0.40$ & $1.09 \pm 0.03$ & $11.32 \pm 0.10$ & $26.6 \pm 0.54$ & $16.1 \pm 2.01$ & $0.20 \pm 0.01$ & $15.9 \pm 2.50$ & $263 \pm 24.1$ & $4.7 \pm 1.20$ \\
\hline ST2 & $1.86 \pm 0.14$ & $6.43 \pm 0.30$ & $1.07 \pm 0.05$ & $12.4 \pm 0.18$ & $74.0 \pm 4.05$ & $20.2 \pm 3.17$ & $0.20 \pm 0.01$ & $21.7 \pm 3.70$ & $593 \pm 38.0$ & $6.10 \pm 1.30$ \\
\hline ST3 & $2.89 \pm 0.25$ & $8.41 \pm 0.42$ & $1.31 \pm 0.16$ & $13.3 \pm 0.20$ & $76.7 \pm 1.17$ & $24.2 \pm 2.56$ & $0.36 \pm 0.02$ & $25.1 \pm 4.00$ & $619 \pm 28.4$ & $10.0 \pm 1.20$ \\
\hline ST4 & $2.33 \pm 0.12$ & $8.43 \pm 0.53$ & $1.26 \pm 0.31$ & $11.8 \pm 0.10$ & $55.4 \pm 2.77$ & $24.0 \pm 3.51$ & $0.21 \pm 0.01$ & $12.2 \pm 2.30$ & $395 \pm 25.6$ & $9.71 \pm 1.32$ \\
\hline ST5 & $2.85 \pm 0.21$ & $7.53 \pm 0.50$ & $1.44 \pm 0.16$ & $12.5 \pm 0.179$ & $46.1 \pm 3.24$ & $24.6 \pm 2.36$ & $0.19 \pm 0.01$ & $21.5 \pm 5.5$ & $374 \pm 26.3$ & $9.60 \pm 1.40$ \\
\hline ST6 & $2.78 \pm 0.10$ & $6.65 \pm 0.55$ & $1.05 \pm 0.02$ & $12.0 \pm 0.11$ & $58.9 \pm 2.60$ & $23.5 \pm 2.00$ & $0.41 \pm 0.01$ & $20.0 \pm 2.31$ & $343 \pm 12.5$ & $9.50 \pm 1.50$ \\
\hline
\end{tabular}

Table 2b: Crassostrea virginica. Elemental concentrations $\left(\left(\mu \mathrm{g} \mathrm{g}^{-1} \mathrm{dry}\right.\right.$-weight $)$ in tissue vs. sediments collected in the winter season

\begin{tabular}{|c|c|c|c|c|c|c|c|c|c|c|}
\hline & $\mathrm{Cd}$ & & $\mathrm{Cr}$ & & $\mathrm{Cu}$ & & $\mathrm{Pb}$ & & $\mathrm{Zn}$ & \\
\hline Sites & Oyst & Sed. & Oyst & Sed. & Oyst & Sed. & Oyst & Sed. & Oyst & Sed. \\
\hline$\overline{\text { ST1 }}$ & $3.78 \pm 0.81$ & $0.144 \pm 0.002$ & $1.12 \pm 0.38$ & $48.79 \pm 4.33$ & $65.0 \pm 7.2$ & $9.92 \pm 2.2$ & $0.40 \pm 0.1$ & $13.1 \pm 5.21$ & $527 \pm 27$ & $492 \pm 2$ \\
\hline ST2 & $3.81 \pm 0.26$ & $0.144 \pm 0.001$ & $1.11 \pm 0.58$ & $89.36 \pm 6.03$ & $84.2 \pm 12.4$ & $18.8 \pm 1.7$ & $0.36 \pm 0.1$ & $28.7 \pm 3.39$ & $837 \pm 38$ & $97 \pm 7$ \\
\hline ST3 & $3.18 \pm 0.25$ & $0.145 \pm 0.002$ & $1.58 \pm 0.62$ & $97.31 \pm 4.87$ & $101 \pm 22.4$ & $18.0 \pm 1.3$ & $0.50 \pm 0.12$ & $32.5 \pm 7.59$ & $1296 \pm 45$ & $103 \pm 12$ \\
\hline ST4 & $3.42 \pm 0.56$ & $0.145 \pm 0.001$ & $1.68 \pm 0.43$ & $91.96 \pm 6.46$ & $108 \pm 21.0$ & $16.0 \pm 2.6$ & $0.40 \pm 0.1$ & $33.3 \pm 2.51$ & $806 \pm 13$ & $97 \pm 4$ \\
\hline ST5 & $3.24 \pm 0.52$ & $0.145 \pm 0.001$ & $2.07 \pm 0.29$ & $84.92 \pm 7.29$ & $73.1 \pm 12.0$ & $17.7 \pm 1.3$ & $0.45 \pm 0.03$ & $30.1 \pm 3.50$ & $614 \pm 18$ & $85 \pm 5$ \\
\hline ST6 & $2.88 \pm 0.16$ & $0.146 \pm 0.001$ & $1.66 \pm 0.25$ & $85.00 \pm 5.00$ & $57.5 \pm 2.3$ & $21.0 \pm 1.3$ & $0.34 \pm 0.04$ & $29.9 \pm 1.11$ & $343 \pm 33$ & $87 \pm 3$ \\
\hline
\end{tabular}

Abbreviations: Oyst = oyster; Sed = sediment; PP = particulate phase

and estuarine sediment (SRM-1646a). The results (Table 1) show good precision for the SRM with an overall $95 \%$ confidence level. In addition, the accuracy of the results was good with respect to the certified values. The recoveries were above $90 \%$ for all trace metals measured except for $\mathrm{Pb}(83 \%)$.

Seasonal and spatial variations: In oyster tissue, metal concentrations (in $\mu \mathrm{g} \mathrm{g}^{-1}$ dry-weight) were between 2.88 and 3.81 for $\mathrm{Cd}, 1.11$ and 2.07 for $\mathrm{Cr}$, 57.5 and 108 for $\mathrm{Cu}, 0.34$ and 0.50 for $\mathrm{Pb}$ and 343 and 1296 for Zn. Similar results were reported for in oyster tissue from Tampa Bay ${ }^{[9]}$. Concentrations of trace metals from certain sites in Apalachicola Bay were high relative to previously reported values for oysters in some slightly contaminated sites in Tampa Bay. The highest reported concentration for $\mathrm{Cd}$ by Fisher was $3.19 \mu \mathrm{g} \mathrm{g}^{-1}$, a value exceeded by oysters from sites 2 and 4 (Fig. 1). Zinc concentration in Site 3 approached the same values reported for the unpolluted sites in Tampa Bay. Furthermore, it appeared that on average concentrations of $\mathrm{Cd}$ and $\mathrm{Pb}$ in Apalachicola bay are higher than values reported values for $\mathrm{Cd}\left(2.8 \mu \mathrm{g} \mathrm{g}^{-1}\right)$ and $\mathrm{Pb}\left(0.51 \mu \mathrm{g} \mathrm{g}^{-1}\right)$ in the Carolinas for the Status and Trends program ${ }^{[10]}$.

Elemental concentrations in oyster tissue are compared to those in the particulate phase (Table $2 \mathrm{a}$ ) in the water column. Concentrations of the selected metals

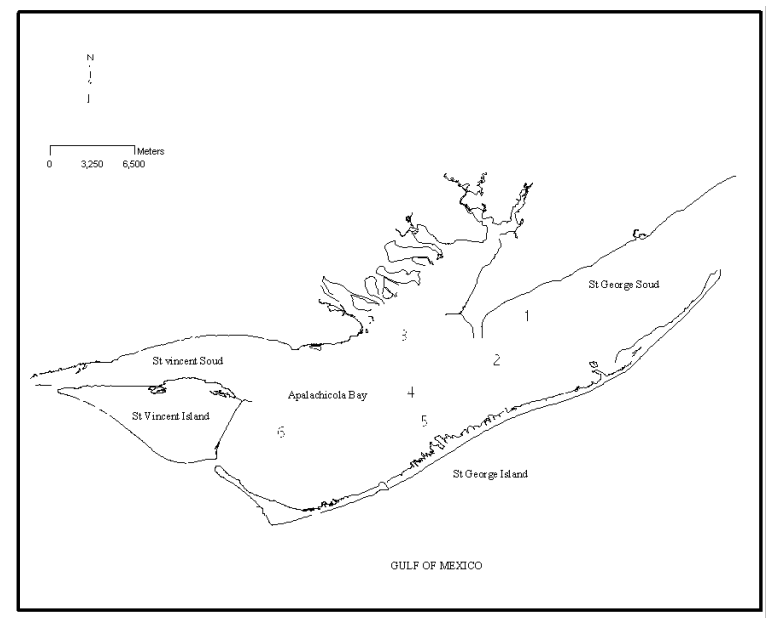

Fig. 1:Map of the study site showing the boundaries, watershed and the six collection sites

in $C$. virginica are three to four orders of magnitude higher than the concentrations in the water column suggesting tissue bioaccumulation.

To assess the spatial distribution of the heavy metals in the estuary, results of elemental concentrations in oysters are compiled in Fig. 2. Utmost concentrations for the metals, $\mathrm{Cu}, \mathrm{Pb}$ and $\mathrm{Zn}$, were found in $C$. virginica from Sites 3, 4 and 5, while the lowest concentrations were found in Site 1. 

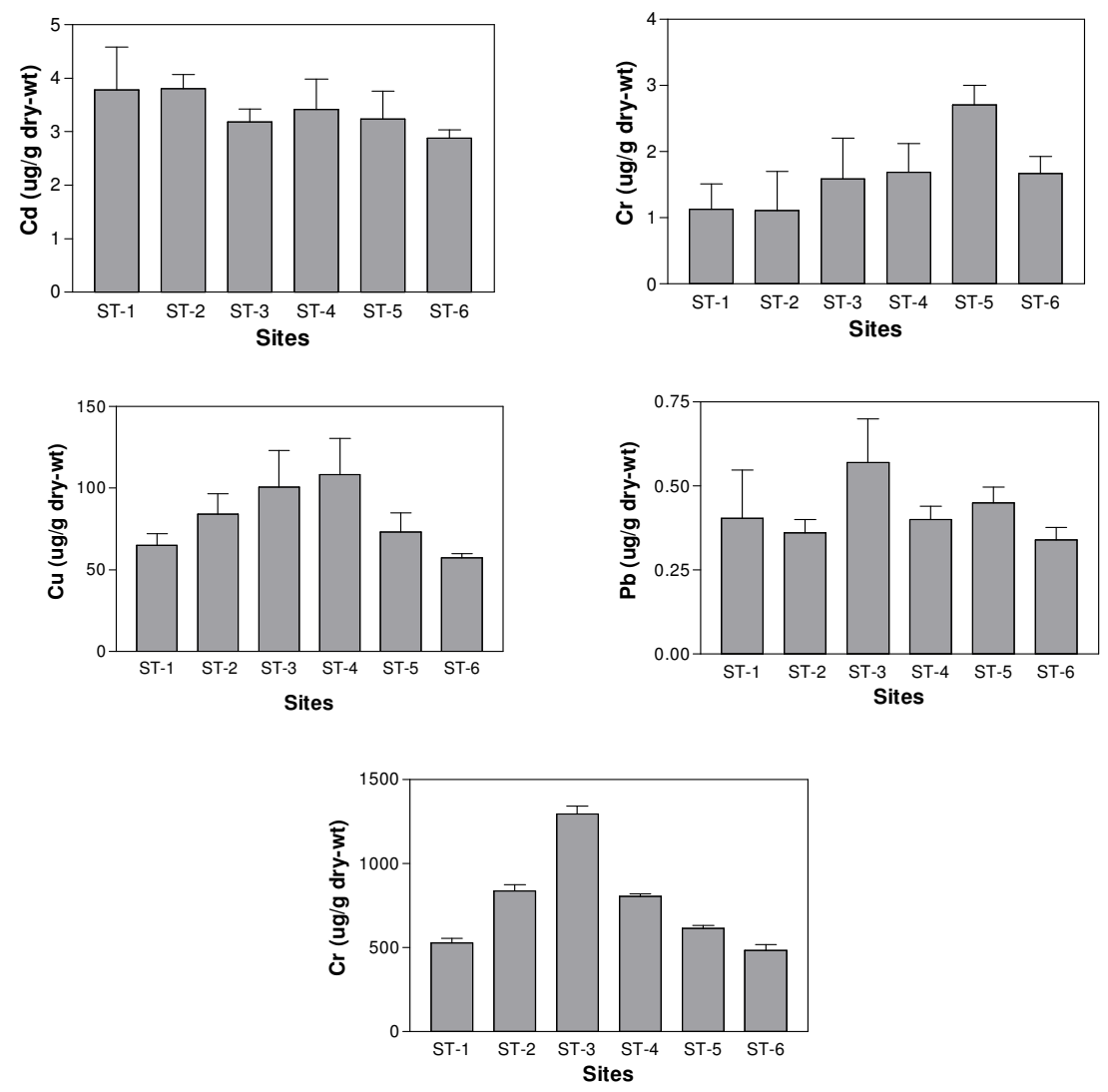

Fig. 2: Crassostrea virginica. Soft tissue metal content showing spatial variations. Mean $\pm 95 \% \mathrm{CL}$
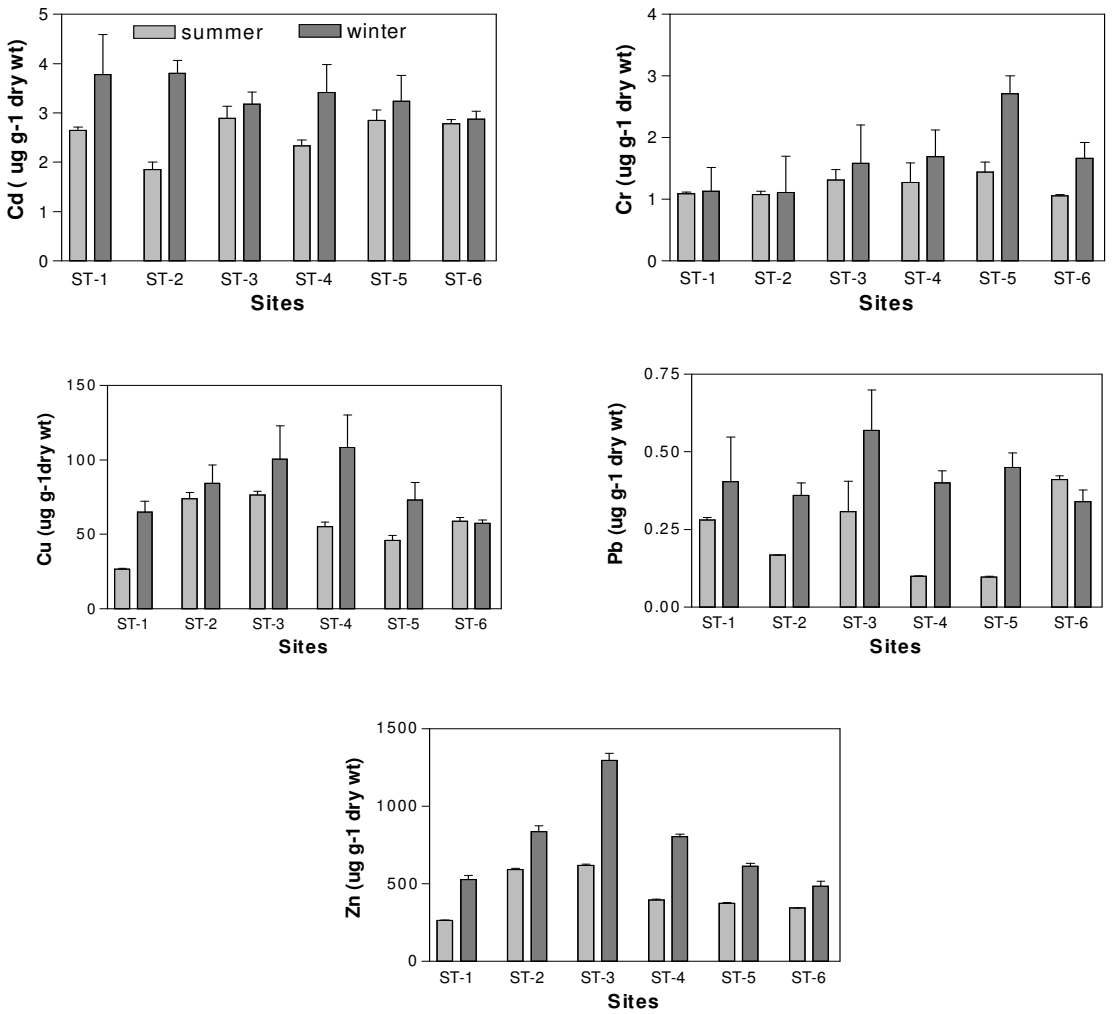

Fig. 3: Crassostrea virginica. Soft tissue metal content showing seasonal variations. Mean $\pm 95 \% \mathrm{CL}$ 
The tissue metal content of oysters collected during the summer and the winter seasons were compared, as shown in Fig. 3. Data in this study show that $C$. virginica collected in the winter tend to have greater metal contents than those collected during the summer months.

C. virginica vs. sediment/particulate matter: Relationships between the metal concentrations in $C$. virginica with respect to elemental concentrations in sediment and water (particulate phase) are illustrated in Fig. 4 and 5. Correlations between $C$. virginica and sediment though positive, were significantly low ( $\mathrm{r}=$ 0.20 for $\mathrm{Pb}, \mathrm{r}=0.10$ for $\mathrm{Cr}$ and $\mathrm{r}=0.10$ for $\mathrm{Zn}$ ) except for $\mathrm{Cu}$ which the coefficient was $\mathrm{r}=0.65$. However, $\mathrm{Cd}$ has a negative coefficient of $r=-0.04$ (Fig. 4). Conversely to the weak correlation with sediment, the relationship between elemental concentrations in oyster tissue and those in the particulate matter show relatively stronger correlation values (Fig. 5). These correlation coefficient $(\mathrm{r})$ values are $0.41,0.63,0.72,0.30$ and 0.50 for $\mathrm{Cd}, \mathrm{Cr}, \mathrm{Cu}, \mathrm{Pb}$ and $\mathrm{Zn}$, respectively.

\section{DISCUSSION}

It has been well documented that the American oyster, Crassostrea virginica, is capable of
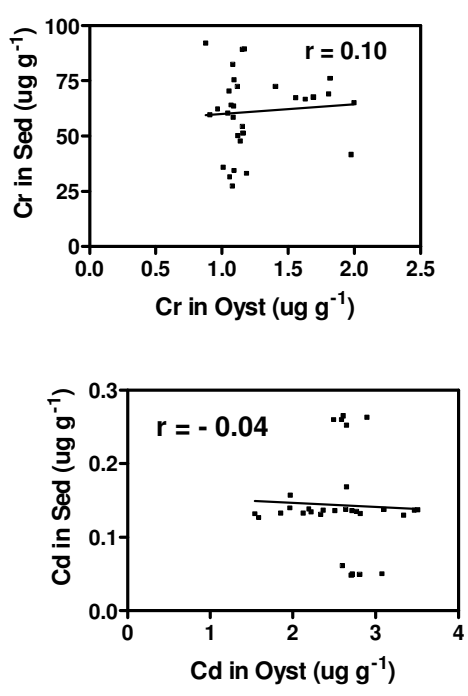

bioaccumulating heavy metals in its soft tissue to levels that are greater than in its corresponding environment $^{[9,11,12]}$. In this study, similar observations were made comparing the elemental concentrations in oyster tissue to those in the water column and surficial sediment (Table $2 \mathrm{a}$ and $2 \mathrm{~b}$ ).

Table $2 \mathrm{~b}$ shows $\mathrm{Cd}, \mathrm{Cu}$ and $\mathrm{Zn}$ levels were greater in the soft tissue of $C$. virginica than in the sediments, while the opposite was true for $\mathrm{Cr}$ and $\mathrm{Pb}$. Elemental concentrations in the oyster tissue collected during both seasons showed the same pattern. The pattern of metal occurrences, in order of decreasing concentrations in $C$ virginica, were $\mathrm{Zn}>\mathrm{Cu}>\mathrm{Cd}>\mathrm{Cr}>\mathrm{Pb}$. Although this pattern could be qualified as specific for Apalachicola Bay, similar patterns were observed elsewhere ${ }^{[6,13,14]}$. The presence in bivalves' soft tissue of sulphur-rich metal complexing proteins (Metallothionein, MT) is responsible of the high content of metal in oysters ${ }^{[11,15]}$. The selective assimilation of metals to different degrees is attributed to the chemistry of the element but more importantly to the MT protein. MT is usually saturated with $\mathrm{Zn}$ and $\mathrm{Cu}$, which can be gradually displaced by other metals particularly $\mathrm{Cd}^{[16]}$. This last suggestion explains well the trend in metal concentration observed in $C$. virginica. This description supports the fact that $\mathrm{Zn}$ and $\mathrm{Cu}$ are found in greater concentrations in oyster tissue.
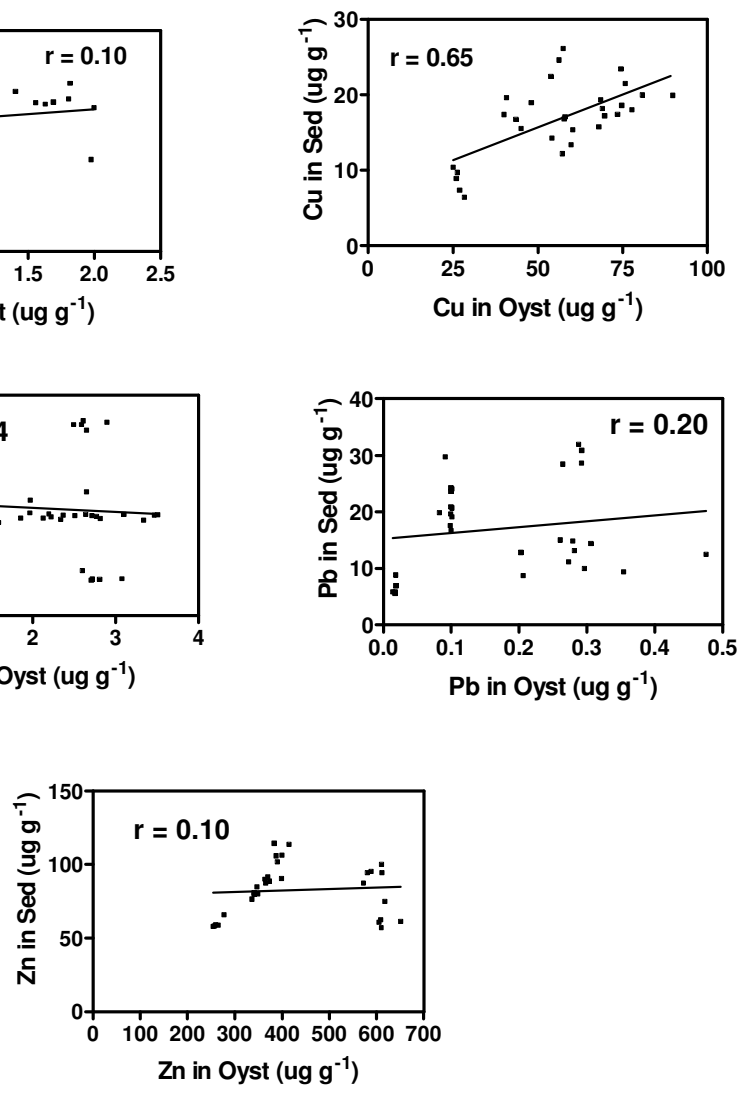

Fig. 4: Crassostrea virginica. Correlation between soft tissue metal content and metal concentrations in surficial sediments. Pearson correlation (r) values are reported 
Am. J. Environ. Sci., 1 (3): 179-186, 2005
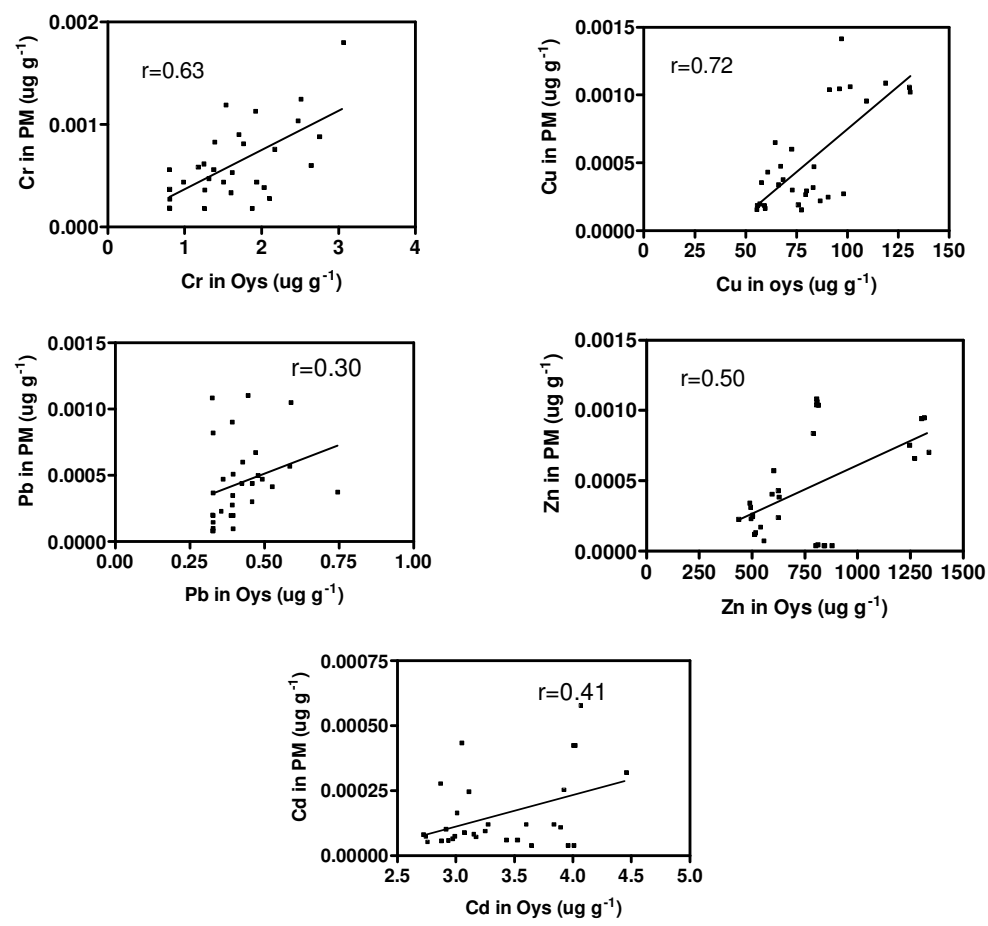

Fig. 5: Crassostrea virginica. Correlation between soft tissue metal content and metal concentrations in particulate phase (PP). Pearson correlation ( $r$ ) values are reported

Patterns of spatial distribution across the study site are shown in Fig. 2. Elements such as $\mathrm{Cu}, \mathrm{Pb}$ and $\mathrm{Zn}$ concentrations in $C$ virginica were consistently greater at Site 3 but significantly lower at Site 1 . Site 3, being the closest to the mouth of the river, has more suspended metal coming from the river and this is translated into higher uptake by the oysters. This observation is in agreement with our prediction that higher metal concentrations will be found in sites with a lot of freshwater influence. Although this can be shown as evidence of spatial differences, $\mathrm{Cd}$ and $\mathrm{Cr}$ concentrations in the oyster in the other hand, show a uniform distribution across the Bay. Results showed that $\mathrm{Cd}, \mathrm{Cr}, \mathrm{Cu}$ and $\mathrm{Pb}$ concentrations at Site 3 were slightly elevated than concentrations at Sites 2, 4, 5 and 6 but the differences are not statistically significant. However, $\mathrm{Zn}$ concentration was significantly greater ( $\mathrm{P}$ $<0.05)$ at Site 3 than at the other Sites. These results demonstrate that metal concentrations in $C$. virginica showed some but not significant patterns of spatial differences in Apalachicola Bay. This observation is probably due to the morphology of the bay which is a very shallow and well-mixed system ${ }^{[2,17]}$. The shallowness (average depth $3 \mathrm{~m}$ ) coupled with the wind driven current, combine to induce a well mix water column in the Apalachicola Bay ${ }^{[18]}$. Consequently, this estuarine mixing results in an uniform distribution of contaminants and across the bay.

The assessment of seasonal variation (Fig. 3) shows that $C$. virginica uptake more heavy metal in winter than summer. This is probably due to the fact that: (1) winter corresponds to the high river flow period where particulate mater concentration is elevated; and (2) oysters in Apalachicola Bay have a higher metabolic rate as they grow fastest in the winter ${ }^{[16]}$. For these reasons, oysters tend to accumulate more metals because their metabolism is greater and metal in particulate phase is relatively more abundant in the winter. The pattern of seasonal variations of metals in tissue, although greater for winter samples, was not uniform across the Bay (site differences). Thus, the metals $\mathrm{Cd}$ and $\mathrm{Cr}$ did not show any statistical difference $(\mathrm{P}>0.05)$ with the exception of Site 2 for $\mathrm{Cd}$ and site 5 for $\mathrm{Cr}$ where the summer results were significantly lower $(\mathrm{P}<0.05)$. Copper showed some statistical differences for the two seasons at sites 1 and 4, while $\mathrm{Cd}$ and $\mathrm{Cr}$ were significantly different at sites 2 and 4 , respectively. For $\mathrm{Pb}$ and $\mathrm{Zn}$ seasonal variations were statistically significant at sites 3 and 4 . These differences could be explained by variations: (1) in the elemental concentrations of the water column and sediment and (2) in the metal bioavailability. During high flow season the discharge of the Apalachicola River increases and so does the turbidity of the system, which induces higher trace metal concentrations in the water. In an effort to investigate relationships between the tissue metal content of $C$. virginica and elemental concentrations in the particulate matter and sediments, respectively, linear regression and correlation analyses were conducted, taking into account all metal pairs at each site.

Although metal $(\mathrm{Cu}, \mathrm{Cr}, \mathrm{Pb}$ and $\mathrm{Zn})$ concentrations in the sediment demonstrated some positive correlation with concentrations in oyster tissue, the correlation is 
not significant (Fig. 4). Similar positive correlation coefficients were reported in Chile ${ }^{[19]}$. However, it is shown in Fig. 4 that the correlation of $\mathrm{Cd}$ is in contrary negative. The behavior of $\mathrm{Cd}$, although opposite to the expectation, is not strange because similar negative correlations were reported ${ }^{[19,20]}$ and it is probably due to the chemistry of $\mathrm{Cd}$ coupled with the processes of adsorption and desorption of metals in saltwater ${ }^{[4]}$. The results then indicate that sediment-bond metals do not directly influence the bioaccumulation in oysters.

Relationships between elemental concentrations in C. virginica and metal concentrations in suspended particles are presented in Fig. 5. In all cases, positive correlations were obtained and the Pearson correlation values were largely greater than those obtained for sediments. Based on correlation coefficients, metal uptake by $C$. virginica could be arranged in order of increasing preference as follows: $\mathrm{Zn}<\mathrm{Cu}<\mathrm{Cr}<\mathrm{Pb}<$ Cd. Again, these patterns could be related to the physiological properties of MT. This observation is conclusive with other studies who suggest that invertebrates take up more zinc in mesohaline estuarine waters $^{[21]}$. These metals could be displaced at the sulphur binding sites by toxic metals and the rate of such displacement by $\mathrm{Cd}$ is higher than other metals making $\mathrm{Cd}$, the third most abundant metal in oyster tissue $\mathrm{e}^{[11,15,16]}$.

\section{CONCLUSION}

Results of this study indicate that in the Apalachicola estuary, concentration of $\mathrm{Cd}, \mathrm{Cu}$ and $\mathrm{Zn}$ were significantly higher in the oyster tissue than in the sediments. However, concentration of $\mathrm{Cr}$ and $\mathrm{Pb}$ were lower compared to levels in the sediment. This suggests that $C$. virginica has more affinity for some metals such as $\mathrm{Cd}, \mathrm{Cu}$ and $\mathrm{Zn}$. Results show that metal concentrations in oyster tissue correlate better with metal concentrations in particulate phase in the water column. This work in Apalachicola Bay elucidated the fact that although oysters dwell on the bottom sediment, their tissue metal content is not at least directly influenced by elemental concentration in the sediment. Instead, oysters preferably uptake metals from the particulate phase in the water column. In addition, differences in tissue metal content showed patterns of temporal and seasonal variations suggesting that $C$. virginica could be a serious candidate as a biomonitoring tool for heavy metals in the Apalachicola estuary.

\section{ACKNOWLEDGEMENTS}

The authors thank the Apalachicola National Estuarine Research Reserve for their assistance. In addition, we are grateful to the NOAA-Environmental Cooperate Science Center grant and the Florida
Agricultural \& Mechanical University Title III grant for providing funding for this research.

\section{REFERENCES}

1. USGS., 1995. Summary of major issues and findings in the Apalachicola-Chattahoochee-Flint River Basin. Water quality in the ACF River basin, 1992-1995.

2. Livingston, R.J., 1983. Resource Atlas of the Apalachicola Estuary. Sea Grant College Program.

3. Marchman, G.L. and N. Wooten, 2000. Analysis of Storm Water to the Apalachicola Bay.

4. Hamelink, J.L., P.F. Landrum, H.L. Bergman and W.H. Benson, 1994. Bioavailability: Physical, chemical and biological interactions. Lewis Publishers CRC Press, Inc. Boca Raton, Florida.

5. Adams, M.A., M. Bolger, C.D. Carrington, C.E. Coker, G.M. Cramer, M.J. DiNovi and S. Dolan, 1993. Guidance Document for Cadmium in Shellfish. US Food and Drug Administration, Center for Food Safety and Applied Nutrition. Washington, DC.

6. NOAA., 1989. A summary of data on tissue contamination from the first three years (19861989) of the Mussel Watch Project. NOAA's State of the Coast Report.

7. Creed, J.T. and T.D. Martin, 1997. Determination of trace elements in marine waters by stabilized temperature graphite furnace atomic absorption. EPA 200.12 National exposure research laboratory office of research and development. US EPA, Cincinnati, $\mathrm{OH}$.

8. Zar, J.H ., 1984. Biostatistical Analysis. 2nd Edn. Prentice-Hall, Englewood Cliffs, N.J.

9. Fisher, W.S., L.M. Oliver, J.T. Winstead and E.R. Long, 2000. A survey of oyster Crassostrea virginica from Tampa Bay, Florida: Associations of internal defense measurements with contaminant burdens. Aquatic. Toxicol., 51: 115-138.

10. O'Connor, T.P., G.G. Lauenstein and A.Y. Cantillo, 2002. The status and trends of trace element and organic contaminants in oysters, Crassostrea virginica, in the waters of the Carolinas, USA. The Science of the Total Environment, 285: 79-87.

11. Kramer, J.M., 1994. Biomonitoring of Coastal Waters and Estuaries. CRC Press, Inc. Boca Raton, Florida.

12. O'Connor, T., 1998. Chemical contaminants oysters, mussels and sediments. NOAA's State of the Coast Report. Silver Spring, MD: NOAA.

13. Lin, S. and I.J.H. Hsieh, 1999. Occurrences of green oyster and heavy metals contaminant levels in the Sien-San Area. Taiwan. Marine Poll. Bull., 38: $960-965$. 
14. Scanes, P.R. and A.C. Roach, 1998. Determining natural 'background' concentrations of trace metals in oysters from New South Wales, Australia.

15. Geret, F. and R.P. Cosson, 1999. Utilisation des metallothioneines comme biomarqueur de la contamination metallique: variabilite entre sites et organes chez l'huitre Crassostrea gigas. Oceanologica Acta, 23: 261-271.

16. Kennedy, V.S. and R.I.E. Newell, 1996. The eastern oyster Crassostrea virginica. Maryland Sea Grant College. University of Maryland system. College park, MD.

17. Huang, W., W.K. Jones and T.S. Wu, 2001. Modeling wind effects on subtidal salinity in Apalachicola Bay, Florida. Estuarine, Coastal and Shelf Sci., Vol. 56.
18. Huang, W. and M. Spaulding, 2002. Modeling residence-time response to freshwater input in Apalachicola Bay, Florida, USA. Hydrol. Process., 16: 3051-3064.

19. Gregori, I.D., H. Pinochet, N. Gras and L. Munoz, 1996. Variability of cadmium, copper and zinc levels in mollusks and associated sediments from Chile. Environ. Poll., 92: 359-368.

20. Hung, T.C., P.J. Meng and B.C. Han, 2001. Trace metals in different species of mollusca, water and sediments from Taiwan coastal area. Chemosphere, 44: 833-841.

21. Rainbow, P.S., 1995b. Physiology, physicochemistry and metal uptake in a crustacean perspective. Marine Poll. Bull., 31: 55-59. 